\title{
Narrative Reflections on Occupational Transitions
}

\author{
Rhysa Leyshon \\ Graduate Program in Health and Rehabilitation, The University of Western Ontario, Elborn College, Rm 2550, \\ London, ON, N6G 1H1, Canada \\ Tel.: +1 5196612111 ext.88979; E-mail: rleyshon@uwo.ca
}

\section{Good things happen in bad times}

Mary's story is one that is likely being repeated around the globe in the wake of the recent economic downturn. The program Mary refers to in her narrative is called Second Careers, run by the Ontario Government. The program was set up specifically for Ontarians who have been laid-off to train for new careers in high demand areas. Applicants are eligible for up to $\$ 28,000$ (Canadian) in financial aide to use towards community college-level educational programs. This is Mary's story of her occupational transition during this major economic recession.

I finished high school but at the time never really thought about having a career. It was just all about having fun back then. I had no thoughts about my future. I know I was very lucky to get the job I did. It was because I had family and friends already working at the plant; that's the only reason I got hired. It sure wasn't because of my resume. I was aware when I was hired that things were different from when my parents worked. I knew I would not be working there for my whole life, but at the same time it wasn't something I really thought about in terms of planning what I would do. Even when I started work, the future of the plant was on shaky ground.

I worked at a manufacturing plant and earned a decent living. But in August of 2008 things changed quickly and initially for the worse. When the plant starting giving out pink slips I had no seniority so I was one of the first to go. I had worked for three years. I knew I had had it good but now there were just no jobs. Even fast food places weren't hiring. And I couldn't compete even if there were jobs. I didn't have any special skills, so if it came down to me or someone with more education I knew that without personal contacts there was no way I would get hired. And most of my family and friends were soon in the same boat as me; they had all been laid off when the plant closed for good a few months later.

It was very fortunate that I had worked for those three years though. I admit I was someone who complained loud and often about taxes, union dues and all the other money that gets taken from each paycheck. I have a very different outlook on that now. I was able to live on the employment insurance money at first but I knew it wouldn't last very long. I have two children and I wanted them to have the life they deserved. I wanted them to be able to do things without having to think about money. I would have had to give up my car and maybe my house. Plus the prospect of finding another decent job was beyond unlikely. Manufacturing was not going to make a big comeback even when and if the economic situation turned around. Those jobs were gone for good.

Through a centre set up by my old union I learned about a program run by the provincial government. The program is for laid off workers to get training in some skill or career at a college. I took this test that tells you what kind of work you would be good at and are interested in. The idea of taking something I was interested in was appealing. I was given enough money to go to school but more importantly I knew that at the end of the program I would have access to a career as opposed to just a job.

I am about halfway through the program now and I have such a great outlook. The school helps us to find jobs and there seem to be quite a few. The last few months of the program are a co-op where the students work at a company to learn more practical skills. We are told that most students end up getting hired fulltime by the company they do the co-op for, so that's encouraging. 
I never thought I disliked my job at the plant. I didn't think about quitting or leaving to find something else but now that I am doing something else I realize I was not very happy or satisfied with my work before. It was just a place I went everyday, put in my time and socialized a bit. I did like my co-workers but it wasn't like I really took pride in what I did. I guess it was like I had no vested interest in my job. It was a paycheck.

My outlook now is very different. I will have more control over the work that I do. It is not just about the money now, it's about proving myself and taking pride in the work I do. It's about building on what I learn at school over a lifetime of work. I'm grateful that these kinds of programs exist and I have a better understanding now of how my taxes are used. Everyone will need a hand up at some point.

I feel badly for those who don't qualify for any programs. I have friends who were just finishing university when the trouble started and can't find jobs now. They had to work to pay for their education. It does seem that skills based careers, like the kind you go to community college to learn about, are in higher demand. But, my friends who never had a job to get laid-off from don't qualify for any kind of programs. I feel a bit guilty sometimes but I also understand what an opportunity I have been given and I will not waste it. I'm jut so excited and eager to finish school and start my career. I don't consider my old job a career it was a job. Thir- teen months ago I never would have imagined I would be attending college and earning a diploma. When all the news about jobs and finances is so gloomy, I am so fortunate to have a bright side. I don't think I would even have thought about going back to school if I had not been laid-off and if there had not been a program that made it easier for me. I had never even considered working in human resources and never even knew I had an interest but taking that test made a big difference. When I was told the results it suddenly seemed like a perfect fit. I just had never been exposed to the possibilities before.

\section{Readers to reflect on}

- Consider that some people may not have a dream not because they lack motivation to reach a goal but because they have never been exposed to the possibilities

- What if everyone who works were allowed to take interest and aptitude tests and then be supported to retrain if necessary, maybe that would result in more efficient, productive and happy workers and save money in the long-term

- Don't complain about taxes and union dues because you never know when you might have to benefit from the programs that the money supports 